\title{
Killing of Human Melanoma Cells by the Membrane Attack Complex of Human Complement as a Function of Its Molecular Composition
}

\author{
D. E. Martin, F. J. Chiu, I. Gigli, and H. J. Müller-Eberhard \\ Division of Molecular Immunology, Research Institute of Scripps Clinic, La Jolla, California 92037; and \\ Division of Dermatology, University of California, San Diego Medical Center, San Diego, California 92103
}

\begin{abstract}
The efficiency of the membrane attack complex (MAC) in killing M21 melanoma cells was determined varying the molar ratio of cell-bound C9:C8. It was found that $(a) C 5 b-8$ produced functional channels as evidenced by ${ }^{86} \mathbf{R b}$ release and propidium iodide uptake; (b) cell killing occurred in the absence of $\mathrm{C} 9$ with $>5$ $\times 10^{5} \mathrm{C} 5 \mathrm{~b}-8 /$ cell; (c) the maximal molar ratio of $\mathrm{C9:C8}$ was 6.6: 1; (d) using nonlytic numbers of C5b-8 (4.7 $\times 10^{5} /$ cell), $>90 \%$ killing ensued at a C9:C8 molar ratio of 2.8:1 at which $\sim 9,000$ poly $\mathrm{C}$ /cell were formed, and $50 \%$ killing at a ratio of $1: 1 ;(e)$ when the MAC was assembled on cells at $0^{\circ} \mathrm{C}$, consisting of $C 5 b-8,9_{1}$, and unbound $C 9$ was removed before incubation at $37^{\circ} \mathrm{C}$, killing was similar to that observed when poly $\mathrm{C} 9$ formation was allowed to occur. Thus, MAC lytic efficiency toward M21 cells may be enhanced by but does not depend on poly $C 9$ formation.
\end{abstract}

\section{Introduction}

Nucleated cells are capable of defense against attack by complement $(1,2)$. Prelytic $(3,4)$ and sublytic $(5)$ doses of complement form functional channels on the plasma membrane of nucleated cells as measured by increased efflux of intracellular ${ }^{86} \mathrm{Rb}$. Cytolytic inefficiency of these channels has been attributed to enhanced cellular metabolic activity (6-8) resulting in inactivation of complement channels by shedding (9) and internalization (10).

The rate of complement channel inactivation by nucleated cells has been attributed to qualitative differences in the membrane attack complex (MAC), ${ }^{1}$ with progressive assembly of the MAC resulting in more rapid channel elimination (10). However, in these experiments, the molecular composition of the MAC and its correlation with lytic efficiency was not determined.

This is Publication No. 4448-IMM from the Department of Immunology, Research Institute of Scripps Clinic. Dr. Chiu's present address is Quidel Pharmaceuticals, 11077 Torrey Pines Road, La Jolla, CA 92037.

Address reprint requests to Dr. Müller-Eberhard, Division of Molecular Immunology, Scripps Clinic and Research Foundation, 10666 North Torrey Pines Road, La Jolla, CA 92037.

Received for publication 29 September 1986 and in revised form 8 January 1987.

1. Abbreviations used in this paper: C8,C9D serum, C8,C9-depleted human serum; HRF, homologous restriction factor, HSA, human serum albumin; MAb, monoclonal antibody; MAC, membrane attack complex; PI, propidium iodide; poly C9, polymerized C9.

J. Clin. Invest.

(C) The American Society for Clinical Investigation, Inc. 0021-9738/87/07/0226/08 $\$ 2.00$

Volume 80, July 1987, 226-233
Although the relationship between MAC structure and function has been extensively studied with erythrocytes, no similar experiments have been performed with nucleated cells. Furthermore, it is unclear whether C5b-9 produces membrane damage through a detergentlike action, as set forth in the "leaky patch" theory (11-13), or through discrete hydrophilic transmembrane protein channels as proposed by the "doughnut" theory (14). Specifically, the role of poly C9, a circular structure containing 12-18 C9 molecules (15-17), in MAC lytic function is not resolved. Direct binding experiments using erythrocytes found C9:C8 molar ratios of 3-4:1 $(18,19), 6: 1(20)$, and 15:1 (17). Marked heterogeneity of MAC size and composition has been reported and related directly to the number of $\mathrm{C} 9$ molecules in the complex $(21,22)$. It was recently demonstrated that thrombin-cleaved $\mathrm{C}$, which is unable to form tubular poly $\mathrm{C}$, retained full hemolytic activity (23). Also, studies have shown varying degrees of lytic activity of complement in the absence of C9 in erythrocytes $(24,25)$, the nucleated cell line U937 (26), and in Giardia lamblia (27), indicating significant membrane labilization by C $5 \mathrm{~b}-8$ complexes. In contrast, several nucleated cell lines appeared to be resistant to lysis by C5b-8 $(4,10)$.

The purpose of this study was to investigate the relationship between binding of the MAC proteins to the target membrane, causation of membrane damage, and cytolysis of the human M21 melanoma cell line. Evidence is presented showing that C5b-8, at high density on the target cell surface, is sufficient to kill M21 melanoma cells. At nonlethal C5b-8 dose, C9 caused efficient killing both at amounts insufficient for overt poly C9 formation and in $\mathrm{C} 9$ excess that produced abundant numbers of circular poly $\mathrm{C} 9$ lesions.

\section{Methods}

Human complement components. C1q (28), C8 (29), and C9 (24) were prepared as described. Purity of the isolated proteins was assessed by sodium dodecyl sulfate (SDS)-polyacrylamide gel electrophoresis using the method of Laemmli (30). Protein concentrations were determined by the Bio-Rad Laboratories (Richmond, CA) assay using bovine gamma globulin as a standard.

Radiolabeling of complement components. Purified C8 and C9 were labeled with ${ }^{125}$ I using the iodogen method (Pierce Chemical Co., Rockford, IL). After labeling, iodinated protein was separated from free ${ }^{125} \mathbf{I}$ by gel filtration on a Sephadex G25 column (PD-10, Pharmacia Fine Chemicals, Piscataway, NJ). The range of specific activity was $1-2 \times 10^{6}$ cpm/ $\mathrm{gg}$. Radiolabeled C8 and C9 retained $85-100 \%$ of their hemolytic activity.

C8 and C 9 depletion of human serum. Normal human serum was depleted of $\mathrm{C} 8$ by affinity chromatography using rabbit anti-C 8 polyclonal IgG coupled to Sepharose 4B (Pharmacia Fine Chemicals). Subsequent C9 depletion was performed using affinity columns prepared from either rabbit anti-C9 polyclonal IgG or a mixture of five high-affinity murine anti-C9 monoclonal antibodies created in this laboratory. Single, double, or repeated passage over these columns yielded complete depletion as assessed by immunochemical and hemolytic criteria. Affinity chromatography was performed in the presence of $10 \mathrm{mM}$ EDTA in veronal- 
buffered saline with subsequent extensive dialysis of depleted serum against buffer without EDTA before storage at $-70^{\circ} \mathrm{C}$. The resulting C8- and C9-depleted serum (C8,9D) was reconstituted with physiologic amounts of purified Clq.

Murine monoclonal antibodies. Monoclonal antibody (MAb) 126.4 , and IgM isotype with specificity for the disialoganglioside GD2, activates human complement on human melanoma cell lines expressing GD2 (31). MAb 9.2.27 (IgG2a) reacts with a melanoma associated chondroitin sulfate proteoglycan and does not activate human complement $(31,32)$. These MAbs were generously provided by Dr. Ralph Reisfeld from this institution.

Target cells. The M21 human melanoma cell line was originally provided by D. L. Morton (University of California, Los Angeles). MAbs 126.4 and 9.2.27 bind homogeneously by fluorescent cytometric analysis. M21 cells were grown in RPMI-1640 supplemented with $10 \%$ heat-inactivated fetal calf serum (Hyclone Laboratories, Logan, UT), $20 \mathrm{mM}$ $\mathrm{L}$-glutamine, and gentamicin at $50 \mu \mathrm{g} / \mathrm{ml}$ medium. They were incubated at $37^{\circ} \mathrm{C}$ with $6 \% \mathrm{CO}_{2}$, and split every $2-3 \mathrm{~d}$ to maintain logarithmic growth. In some cultures Hyclone was replaced by $1 \%$ Nutridoma (Boerhinger Mannheim Biochemicals, Indianapolis, IN) $24 \mathrm{~h}$ before harvesting. After harvesting, cells were washed three times in RPMI supplemented with $1 \%$ human serum albumin (Calbiochem/Behring Diagnostics, La Jolla, CA). This medium (RPMI-HSA) was used for all experiments. Viability, determined by trypan blue exclusion, was $>90 \%$.

Radiolabeling of target cells. $5 \times 10^{6} \mathrm{M} 21$ cells in $1 \mathrm{ml}$ of RPMIHSA were labeled with either $150 \mu \mathrm{Ci}$ of ${ }^{51} \mathrm{Cr}$ or $400 \mu \mathrm{Ci}$ of neutralized ${ }^{86} \mathrm{Rb}$ (New England Nuclear, Boston, $\mathrm{MA}$ ) for $1 \mathrm{~h}$ at $37^{\circ} \mathrm{C}$ with $6 \% \mathrm{CO}_{2}$, washed three times, and resuspended to $1 \times 10^{6} / \mathrm{ml}$. Specific activities were 5,000-10,000 and 15,000-20,000 cpm/2.5 $\times 10^{4}$ cells after ${ }^{51} \mathrm{Cr}$ and ${ }^{86} \mathrm{Rb}$ labeling, respectively.

Radioisotype release assay. Reactions were performed in duplicate in $12 \times 75$-mm polypropylene tubes (Costar, Cambridge, MA). Labeled M21 cells at $1 \times 10^{6} / \mathrm{ml}$ were incubated with an equal volume of appropriately diluted MAb 126.4 for $30 \mathrm{~min}$ at $37^{\circ} \mathrm{C}, 6 \% \mathrm{CO}_{2}$. C8,9D serum, reconstituted with varying doses of $\mathrm{C} 8$ and $\mathrm{C} 9$, was then added at a final dilution of 1:4 for further incubation. At various times, aliquots containing $2.5 \times 10^{4}$ cells were withdrawn and immediately centrifuged. $75 \mu$ of supernatant was subjected to radioactivity measurements and percent specific release was calculated by the formula: [(experimental - spontaneous) $\mathrm{cpm}] /[$ maximal - spontaneous) $\mathrm{cpm}] \times 100$. Maximal release was determined by lysis with $0.1 \%$ NP40. Controls included C8,9D serum alone, and substitution of MAb 9.2.27 for MAb 126.4. In some experiments, where lysis was compared at 0 and $37^{\circ} \mathrm{C}$, antibody-sensitized, ${ }^{51} \mathrm{Cr}$-labeled cells were incubated with $\mathrm{C} 8,9 \mathrm{D}$ serum for $15 \mathrm{~min}$ at $37^{\circ} \mathrm{C}$. Aliquots were subsequently placed at 0 or $37^{\circ} \mathrm{C}$, and varying amounts of $\mathrm{C} 8$ or $\mathrm{C} 8+\mathrm{C} 9$ were added. Specific lysis was measured after 60 min at 0 or $37^{\circ} \mathrm{C}$. Cells at $0^{\circ}$ were washed at $4^{\circ} \mathrm{C}$ to remove unbound

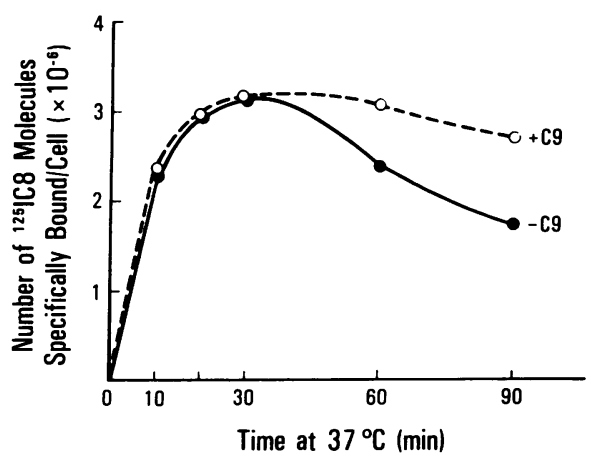

Figure 1. Specific uptake of C8 by M21 melanoma cells in the presence and absence of C9. MAb-sensitized M21 cells were incubated with $\mathrm{C} 8,9 \mathrm{D}$ serum reconstituted with ${ }^{125} \mathrm{I}-\mathrm{C} 8(60 \mu \mathrm{g} / \mathrm{ml})$ in the presence and absence of $C 9(60 \mu \mathrm{g} / \mathrm{ml})$. At various times aliquots were processed to determine specific uptake as described in Methods. Results are the mean of three experiments with a standard deviation of $<7 \%$ for each data point.

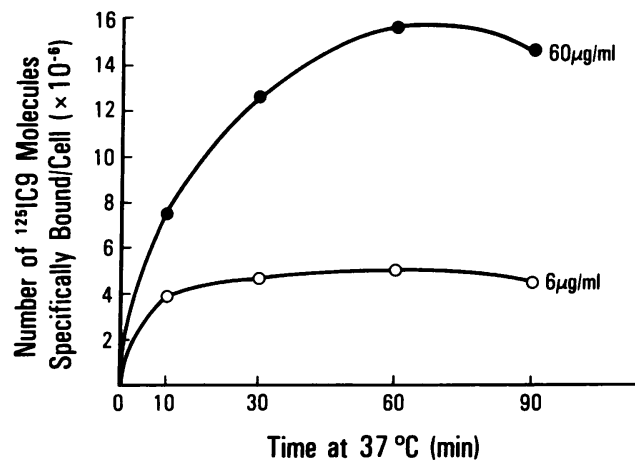

Figure 2. Specific uptake of C9 by M21 melanoma cells at different C8 concentrations. C8,9D serum was reconstituted with 6 or $60 \mu \mathrm{g} / \mathrm{ml}$ of $\mathrm{C} 8$ and ${ }^{125} \mathrm{I}-\mathrm{C} 9(60 \mu \mathrm{g} / \mathrm{ml})$ corresponding to $\mathrm{C} 9: \mathrm{C} 8$ molar ratios of 2:1 and 20:1. Nonspecific binding determined by omission of $\mathrm{C8}$ was $<12 \%$ for each data point.

$\mathrm{C} 8$ and $\mathrm{C} 9$ and incubated at $37^{\circ} \mathrm{C}$ for $60 \mathrm{~min}$, and lysis was again measured.

Deposition of ${ }^{125} I-C 8$ and ${ }^{125} I-C 9$ on M21 cells. Binding experiments were performed in identical fashion as radioisotope release assays, except that ${ }^{125} \mathrm{I}-\mathrm{C} 8$ or ${ }^{125} \mathrm{I}-\mathrm{C} 9$ was substituted for the unlabeled component. After various incubation intervals, aliquots containing $2.5 \times 10^{4}$ cells were layered onto $300 \mu \mathrm{l}$ of a 1:1 mixture of dibutyl and dioctyl phthalate (Eastman Kodak Co., Rochester, NY) in 400- 1 l polyethylene tubes (BioRad Laboratories), and immediately centrifuged for $1 \mathrm{~min}$ in a Beckman Microfuge B (Beckman Instruments, Inc., Fullerton, CA). Specific binding was calculated by the formula: $100 \times[$ (pellet) $\mathrm{cpm}] /[$ (pellet + supernatant) cpm] - \% nonspecific binding. For C8, nonspecific binding was determined by incubation with MAb 9.2.27 instead of 126.4 or with no antibody, yielding identical results. C9-nonspecific binding was determined by omitting $\mathrm{C} 8$. Each time point with its corresponding controls was performed in triplicate.

Determination of propidium iodide (PI) uptake using fluorescent cytometric analysis. Incubations and dilutions were identical to radioisotope release assays. At various times, aliquots containing $3 \times 10^{5}$ cells were removed and immediately placed on ice. $3 \mathrm{ml}$ of iced phosphate-buffered saline (PBS), pH 7.4, containing $5 \mu \mathrm{g} / \mathrm{ml}$ of PI (Sigma Chemical Co., St. Louis, MO) (PI-PBS) was added, and the mixture was incubated in the dark for $15 \mathrm{~min}$. The cells were then washed twice with $3 \mathrm{ml}$ of iced PBS, resuspended to $400 \mu$ l of PBS, and remained on ice until analysis by fluorescent cytometry. Fluorescent cytometric measurements were made in a Becton-Dickinson (Mountain View, CA) FACS IV using an argon-ion laser at $488 \mathrm{~nm}$ fitted with a dichroic mirror (570 DM), and a 625/35-nm band pass filter to detect PI (FL2).

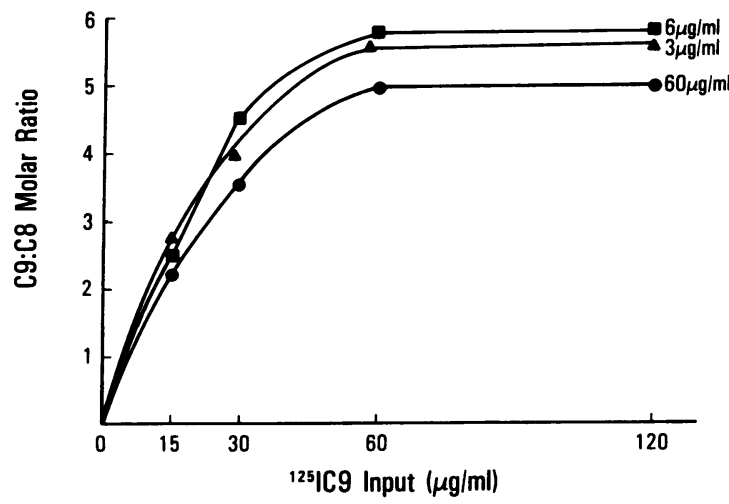

Figure 3. Molar ratio of $\mathrm{C} 9: \mathrm{C} 8$ bound to M21 melanoma cells at different $\mathrm{C} 8$ concentrations $(3,6$, and $60 \mu \mathrm{g} / \mathrm{ml})$. The C9:C8 ratio was calculated from binding studies as described in Figs. 1 and 2. 


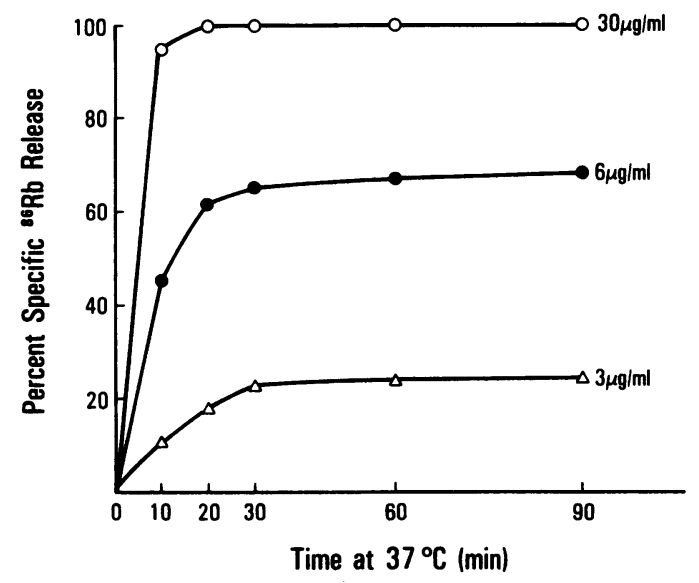

Figure 4. Kinetics of ${ }^{86} \mathrm{Rb}$ release from M21 melanoma cells at different $\mathrm{C} 8$ concentrations $(3,6$, and $30 \mu \mathrm{g} / \mathrm{ml})$ in the absence of C9. Maximal release was determined using $0.1 \%$ NP-40. Spontaneous release was $15 \%$ at $60 \mathrm{~min}$. Each data point was determined in duplicate.

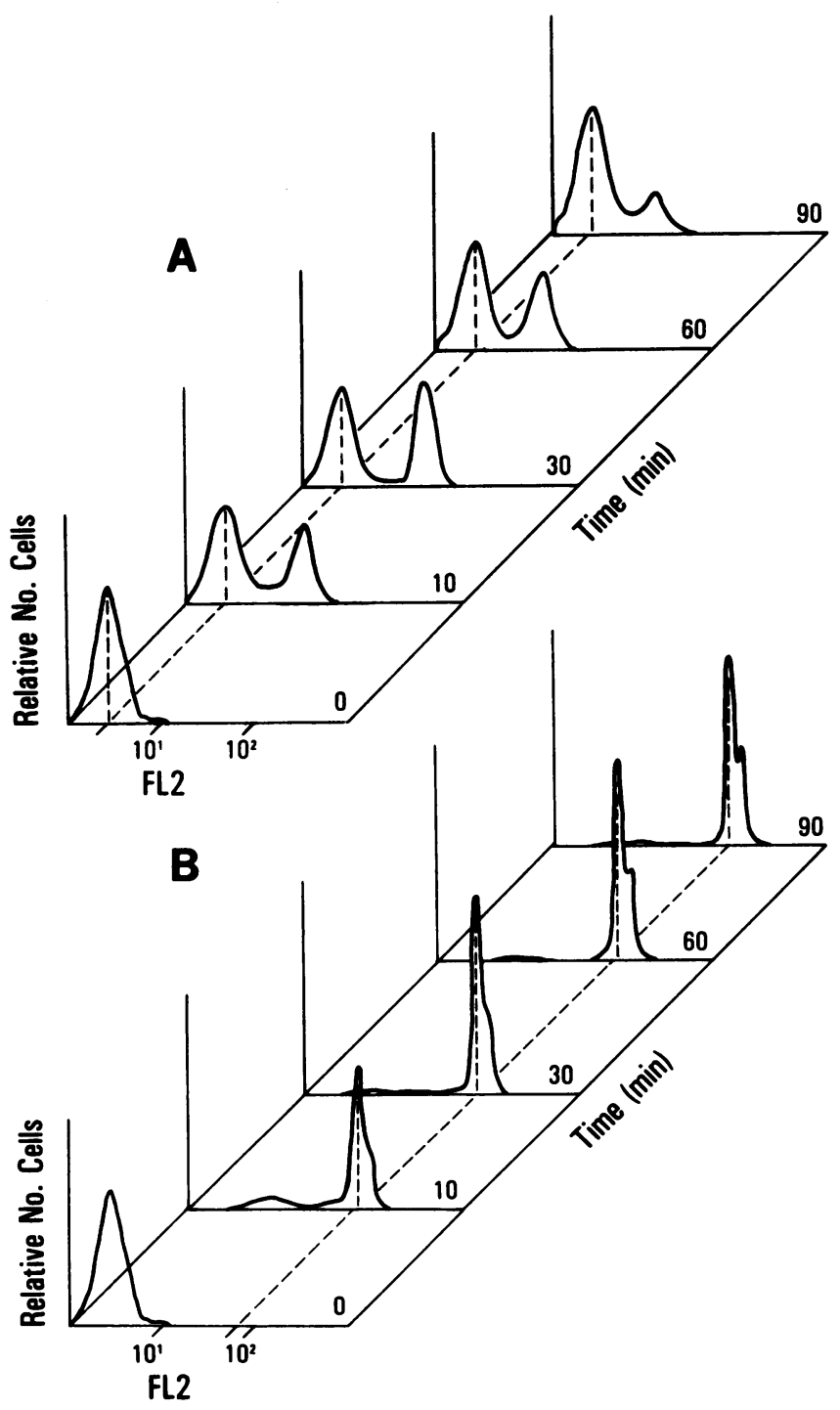

Figure 5. Fluorescent cytometric analysis of PI (FL2) uptake by M21 cells. Cells were incubated at $37^{\circ} \mathrm{C}$ with $\mathrm{C} 8,9 \mathrm{D}$ serum reconstituted with $C 8(6 \mu \mathrm{g} / \mathrm{ml})(A)$ in the absence of C9 and $(B)$ with $C 9(60 \mu \mathrm{g} /$ $\mathrm{ml})$. At various times, aliquots were placed on ice and treated with PIPBS as outlined in Methods.
Electron microscopy. Incubations and dilutions were as described above for kinetic assays. For transmission electron microscopy, $2 \times 10^{4}$ cells were washed twice in PBS and resuspended in $1 \mathrm{ml}$ of $5 \mathrm{mM} \mathrm{Na}$ -

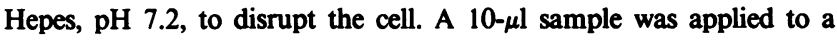
carbon-coated grid, $\mathbf{4 0 0}$ mesh, and left at room temperature for $30 \mathrm{~min}$ to dry. Negative staining was then performed with $1 \%$ uranyl formate for $30 \mathrm{~s}$ with excess removed by blotting on filter paper. The grid was examined with a Hitachi 12A transmission electron microscope (Tokyo, Japan) using an acceleration voltage of $75 \mathrm{kV}$ and magnification of 30,000 or 60,000 . For scanning electron microscopy, similar samples were fixed in modified Karnovsky's fixative (1.5\% glutaraldehyde and $2 \%$ paraformaldehyde in $0.1 \mathrm{M}$ cacodylate buffer, $\mathrm{pH} 7.4$ ) at $4^{\circ} \mathrm{C}$ for $1 \mathrm{~h}$, followed by rinsing and deposition onto glass slides precoated with poly-L-lysine. Samples were dried, carbon coated, and observed with a Hitachi S 500 scanning electron microscope operating at $20 \mathrm{kV}$ accelerating voltage.

Analysis of MAC-associated poly C9 by SDS polyacrylamide gradient gel electrophoresis. $1 \times 10^{5} \mathrm{M} 21$ cells in $0.1 \mathrm{ml}$ of RPMI-HSA were treated as in previous experiments with reconstitution of $\mathrm{C8,9D}$ serum with $\mathrm{C} 8$ and ${ }^{125} \mathrm{I}-\mathrm{C} 9$. After $60 \mathrm{~min}$ of incubation at $37^{\circ} \mathrm{C}, 6 \% \mathrm{CO}_{2}$, the cells were washed once with $\mathrm{PBS}$ and lysed with $\mathrm{H}_{2} \mathrm{O}$. After centrifugation, sediments were dissolved in $70 \mu \mathrm{l}$ of $4 \%$ SDS with $1 \% \beta$-mercaptoethanol, boiled for 15-20 min, and subjected to electrophoresis on $2.5-10 \%$ polyacrylamide gradient slab gels utilizing the Laemmli system. Controls on every gel included tubular poly $\mathrm{C} 9$ generated by addition of $50 \mu \mathrm{M} \mathrm{Zn}^{2+}$ and prolonged incubation at $37^{\circ} \mathrm{C}$, monomeric $\mathrm{C}$, and ${ }^{125} \mathrm{I}-\mathrm{C} 9$. Gels were stained with Coomassie Brilliant Blue and sliced in $0.5-1-\mathrm{cm} \mathrm{sec-}$ tions, and radioactivity was measured to determine the fraction of bound C9 converted to SDS-resistant poly C9. > $1 \%$ of the ${ }^{125} \mathrm{I}-\mathrm{C} 9$ control migrated as the $1.1 \times 10^{6} \mathrm{~mol}$ wt SDS-resistant poly C9.

\section{Results}

Kinetic analysis of radiolabeled C8 and C9 uptake by $M 21$ melanoma cells. Fig. 1 shows a kinetic analysis of binding of ${ }^{125} \mathrm{I}-$ C8 $(60 \mu \mathrm{g} / \mathrm{ml})$ in the presence and absence of unlabeled C9. Uptake curves were identical during the first $30 \mathrm{~min}$ when maximal binding occurred. The discrepancy between the two curves at times $>30 \mathrm{~min}$ is probably attributable to the slower kinetics of killing in the absence of $\mathrm{C} 9$ allowing active shedding of C5b8 complexes. Specific ${ }^{125} \mathrm{I}-\mathrm{C} 9$ binding was saturable at physiologic concentrations $(60 \mu \mathrm{g} / \mathrm{ml})$, independent of $\mathrm{C} 8$ concentration, and was not enhanced by five times physiologic doses of $\mathrm{C} 9$ (not shown). Fig. 2 is a kinetic analysis of $\mathrm{C} 9$ uptake at saturating

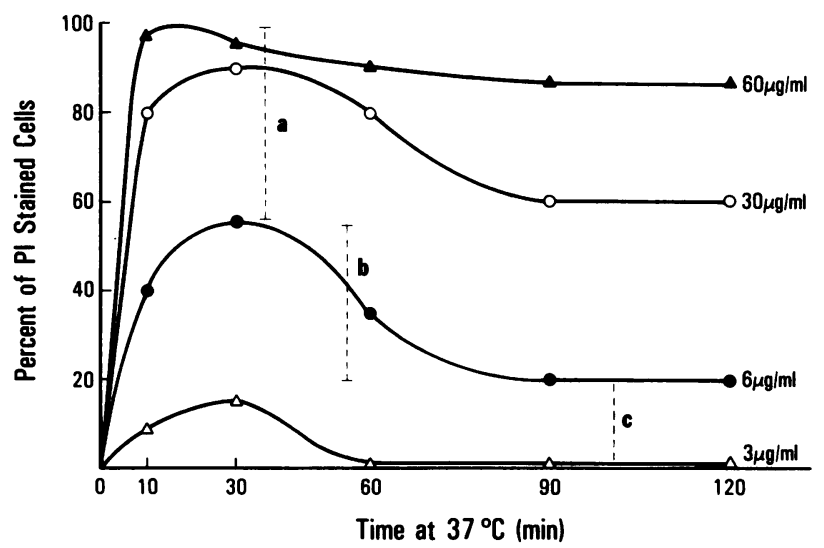

Figure 6. Kinetics of PI uptake by M21 cells at different C8 concentrations $(3,6,30$, and $60 \mu \mathrm{g} / \mathrm{ml})$ in the absence of C9. PI uptake profiles, derived from serial fluorescence histogram analyses as in Fig. 5, reveal three subpopulations of cells indicated in the figure for the 6$\mu \mathrm{g} / \mathrm{ml} \mathrm{C8}$ dose: (a) resistant, $(b)$ reversibly damaged, $(c)$ irreversibly damaged. 
Table I. Recovery of M21 Melanoma Cells Attacked by $C 5 b-8$ or $C 5 b-9$ (at Nonlytic C8 Concentration) as Measured by Propidium Iodide Uptake*

\begin{tabular}{lllll}
\hline & \multicolumn{3}{l}{$\begin{array}{l}\text { Percent cells with } \\
\text { PI uptake }\end{array}$} & $\begin{array}{l}\text { Percent } \\
\text { recovery }\end{array}$ \\
\cline { 2 - 4 }$\mu \mathrm{g} / \mathrm{ml}$ Concn. & C9 Concn. & $30 \mathrm{~min}$ & $90 \mathrm{~min}$ & \\
3 & $\mu g / m l$ & $\%$ & $\%$ & \\
6 & 0 & 15 & 0 & 100 \\
30 & 0 & 55 & 20 & 64 \\
3 & 0 & 90 & 60 & 33 \\
3 & 1.5 & 45 & 20 & 55 \\
3 & 3 & 60 & 35 & 38 \\
3 & 6 & 90 & 72 & 20 \\
& 60 & 97 & 92 & 5 \\
\hline
\end{tabular}

* M21 cells $\left(1 \times 10^{6}\right.$ cells $\left./ \mathrm{ml}\right)$ were incubated with C8,9D serum containing various doses of $\mathrm{C} 8$ or $\mathrm{C} 8$ and C9. At indicated times, aliquots containing $3 \times 10^{5}$ cells were removed and briefly incubated with propidium iodide as described in Methods. Percent recovery is derived from the ratio of PI-positive cells at 90 and $30 \mathrm{~min}$. Results are the mean of three experiments with standard deviations of $<10 \%$ of each number.

doses with $\mathrm{C} 8$ concentrations corresponding to $\mathrm{C} 9: \mathrm{C} 8$ molar ratios of 2:1 and 20:1. The molar ratio of bound C9:C8 was determined as a function of $\mathrm{C} 9$ concentration (Fig. 3) at various C8 concentrations. The C9:C8 ratio was maximal at physiologic concentrations of $C 9$ with the plateau at $60 \mathrm{~min}$ as predicted from the delayed $\mathrm{C} 9$ binding relative to $\mathrm{C} 8$ (Figs. 1 and 2).

Formation and elimination of $C 5 b-8$ and $C 5 b-9$ channels in M21 melanoma cells. The kinetics of intracellular ${ }^{86} \mathrm{Rb}$ release as a function of $\mathrm{C} 8$ concentration in absence of $\mathrm{C} 9$ is shown in Fig. 4. Rapid total release was observed with $\mathrm{C} 8$ at high concentrations $(30 \mu \mathrm{g} / \mathrm{ml})$. Rapid, but submaximal, transmembrane ion flux was seen at decreasing doses of $\mathrm{C} 8(6$ and $3 \mu \mathrm{g} / \mathrm{ml})$ with plateauing at $\sim 30 \mathrm{~min}$ of incubation, corresponding to maximal C8 binding.

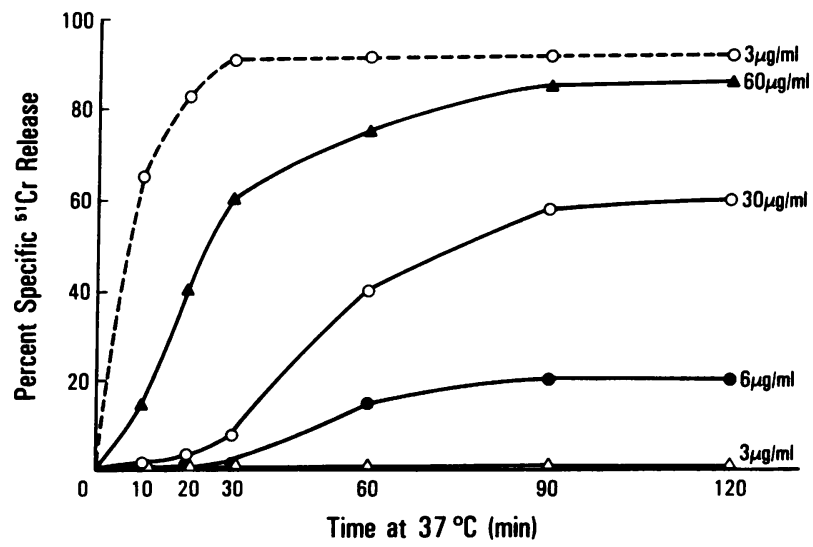

Figure 7. Killing of M21 melanoma cells in the absence of $\mathrm{C} 9$ at different $\mathrm{C} 8$ concentrations $(3,6,30$, and $60 \mu \mathrm{g} / \mathrm{ml})$. Kinetics of specific ${ }^{51} \mathrm{Cr}$ release were determined as outlined in Methods. Dashed line represents lysis due to addition of $\mathrm{C} 9(60 \mu \mathrm{g} / \mathrm{ml})$ to a nonlytic dose of $\mathrm{C} 8$ $(3 \mu \mathrm{g} / \mathrm{ml})$. Results are the mean of three experiments with a standard deviation of $<5 \%$ for each data point. Spontaneous ${ }^{51} \mathrm{Cr}$ release was $7-10 \%$ at $120 \mathrm{~min}$.

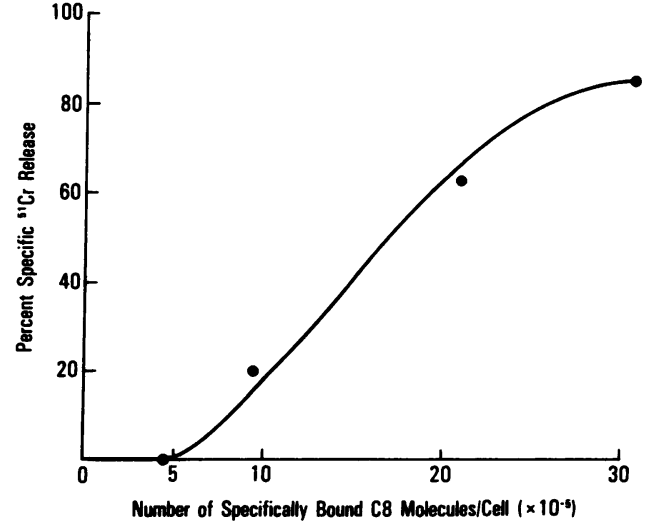

Figure 8. Killing of M21 melanoma cells by cell-bound C $5 \mathrm{~b}-8$ in the absence of $\mathrm{C} 9 .{ }^{51} \mathrm{Cr}$ release and ${ }^{125} \mathrm{I}-\mathrm{C} 8$ uptake were determined in parallel experiments. Incubation time was $30 \mathrm{~min}$ for ${ }^{125} \mathrm{I}-\mathrm{C} 8$ and $90 \mathrm{~min}$ for ${ }^{51} \mathrm{Cr}$ release. Spontaneous ${ }^{51} \mathrm{Cr}$ release was 5-9\% at $90 \mathrm{~min}$.

The second method of measuring loss of membrane integrity as a consequence of functional complement channel formation was the uptake of PI. Fig. $5 A$ shows serial histograms obtained by fluorescent cytometric analysis of PI uptake as a function of time at a $\mathrm{C} 8$ concentration of $6 \mu \mathrm{g} / \mathrm{ml}$ in the absence of $\mathrm{C} 9$. A shift is observed in the distribution of cells capable of excluding PI, with stabilization at $90 \mathrm{~min}$. Fig. $5 B$ shows the results of adding a physiologic amount of $\mathrm{C} 9(60 \mu \mathrm{g} / \mathrm{ml})$. In comparing the positively fluorescent cells in Fig. 5, $A$ and $B$, it can be seen that there are two different intensities. The positively stained cells in Fig. $5 \mathrm{~A}$ have a diffuse cytoplasmic staining pattern by fluorescence microscopy, reflecting loss of plasma membrane integrity. Positively stained cells in Fig. $5 B$ have, in addition, very brightly stained nuclei, reflecting loss of integrity of both plasma and nuclear membranes. These observations are consistent with the 100-fold increase in quantum fluorescence efficiency of PI upon intercalation with DNA.

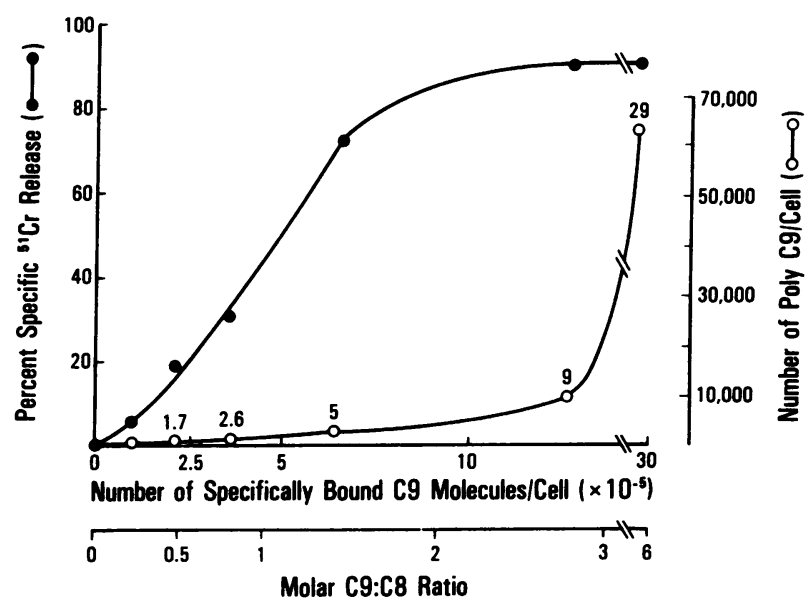

Figure 9. Killing of M21 melanoma cells in relation to number of specifically bound $\mathrm{C} 9$ molecules per cell and to the molar $\mathrm{C} 9: \mathrm{C} 8$ ratio. Cells were incubated with C8,9D serum, reconstituted with a nonlytic dose of $\mathrm{C} 8(3 \mu \mathrm{g} / \mathrm{ml})$ and varying doses of $\mathrm{C} 9$ for $90 \mathrm{~min}$ at $37^{\circ} \mathrm{C}$. Numbers above open circles indicate percentage of cell-bound $C 9$ molecules participating in SDS-resistant poly $\mathrm{C}$. Spontaneous ${ }^{51} \mathrm{Cr}$ release was $5-9 \%$ at $90 \mathrm{~min}$. 


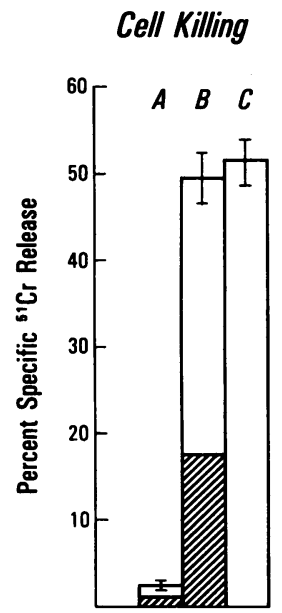

C8 $\quad$ C8,9 C8,9

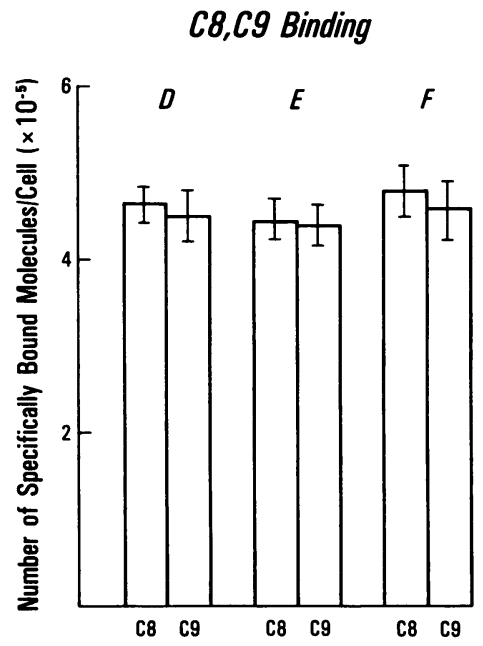

Figure 10. Killing of M21 melanoma cells by $\mathrm{C} 5 \mathrm{~b}-8_{1} 9_{1}$ at $0^{\circ} \mathrm{C}$ and $37^{\circ} \mathrm{C}$. ${ }^{51} \mathrm{Cr}$-labeled cells were incubated with $\mathrm{C} 8,9 \mathrm{D}$ serum for $15 \mathrm{~min}$ at $37^{\circ} \mathrm{C} .(A, B)$ Cells were then placed at $0^{\circ} \mathrm{C}$ and $\mathrm{C} 8(3 \mu \mathrm{g} / \mathrm{ml})$ or $\mathrm{C} 8$ $+\mathrm{C} 9(3 \mu \mathrm{g} / \mathrm{ml})$ were added with incubation for $60 \mathrm{~min}$, when specific lysis was measured (shaded columns). Aliquots were subsequently washed at $4^{\circ} \mathrm{C}$ to remove free $\mathrm{C} 8$ and $\mathrm{C} 9$ and lysis was measured after incubation at $37^{\circ} \mathrm{C}$ for $60 \mathrm{~min}$ (unshaded columns). $(C)$ Cells were incubated only at $37^{\circ} \mathrm{C}$ for $60 \mathrm{~min}$. Spontaneous ${ }^{51} \mathrm{Cr}$ release was 6-9\%. Under identical conditions, unlabeled cells were incubated with ${ }^{125} \mathrm{I}$ $\mathrm{C} 8$ or $\mathrm{C} 9$ as described in methods. $(D) \mathrm{C} 8, \mathrm{C} 9$ binding to cells incubated for $60 \mathrm{~min}$ at $0^{\circ} \mathrm{C}$. (E) Aliquots washed at $4^{\circ} \mathrm{C}$ and incubated for $60 \mathrm{~min}$ at $37^{\circ} \mathrm{C}$. $(F)$ Cells incubated for $60 \mathrm{~min}$ at $37^{\circ} \mathrm{C}$ only. C9: C8 ratio was $\sim 1: 1$. Error bars indicate the mean of three measurements \pm standard error of the mean.

Fig. 6 graphically depicts the kinetics of PI uptake at various C8 concentrations without C9. Analysis of C5b-8 mediated PI uptake profiles reveals three subpopulations of cells: (a) resistant, with no PI uptake; $(b)$ reversibly damaged, regaining the ability to exclude PI with further incubation; and $(c)$ irreversibly damaged, with a stable PI uptake at $90 \mathrm{~min}$. These subpopulations are indicated in Fig. 6 for the $6 \mu \mathrm{g} / \mathrm{ml}$ dose of C8. Table I shows the relative recovery of $\mathrm{M} 21$ cells ranging $14-100 \%$ at various C8 doses in absence of C9. Addition of various doses of C9 to nonlytic amounts of C5b-8 markedly reduced the number of cells capable of eliminating complement channels (5-55\%).

Killing of M21 melanoma cells by C5b-8. Fig. 7 shows the kinetics of ${ }^{51} \mathrm{Cr}$ release at different $\mathrm{C} 8$ doses without $\mathrm{C}$. $\mathrm{C5b}-8$ mediated lysis was maximal at $90 \mathrm{~min}$, and the final extent of the reaction was markedly sensitive to $\mathrm{C} 8$ concentration. At a C8 input of $60 \mu \mathrm{g} / \mathrm{ml}$, lysis approached $85 \%$ and $3.1 \times 10^{6} \mathrm{C} 8$ molecules were specifically bound per cell (Fig. 8). At $6 \mu \mathrm{g}$ of input, lysis was $20 \%$ and $900,000 \mathrm{C} 8$ molecules were bound. At the lowest input $(3 \mu \mathrm{g} / \mathrm{ml}), 470,000 \mathrm{C} 8$ molecules were still bound per cell, but no killing was observed although membrane leakiness was detectable by ${ }^{86} \mathrm{Rb}$ release (Fig. 4) and PI uptake (Fig. 6). With addition of physiologic amounts of $C 9$ to the nonlytic amount of $\mathrm{C} 8(3 \mu \mathrm{g} / \mathrm{ml})$ lysis was rapid, reaching maximal ${ }^{51} \mathrm{Cr}$ release at $30 \mathrm{~min}$. The shape of the kinetic curves of C8-dependent lysis (Fig. 7) and the sigmoidal dose response curve (Fig. 8) suggest cooperativity of $\mathrm{C} 8$ sites on the target cell to achieve effective membrane lesions. This is also suggested by the high number of $\mathrm{C} 8$ sites required for lysis in absence of $\mathrm{C} 9$.

Killing of M21 melanoma cells in relation to the molar ratio of cell bound C9:C8 and poly C9 formation. Fig. 9 depicts C9 lytic efficiency as a function of the number of specifically bound
C9 molecules and the C9:C8 molar ratio at a nonlytic dose of $\mathrm{C} 8(3 \mu \mathrm{g} / \mathrm{ml})$. Also indicated is the extent of poly C9 formation under these conditions. Maximal killing was achieved at a C9: C8 ratio of 3:1, with $<10 \%$ of bound C9 converted to poly C9. At a molar C9:C8 ratio of 1:1, killing was $~ 50 \%$ and of the 470,000 C9 molecules bound per cell, $\sim 12,000$ participated in the formation of the 1,000 SDS-resistant poly C9 structures detected. To further evaluate the contribution of these poly $\mathrm{C} 9$ structures to cell lysis, ${ }^{51} \mathrm{Cr}$-release and C8,C9-binding measurements were performed at $0^{\circ} \mathrm{C}$ (Fig. 10). Under these conditions, C5b-7-treated cells bind C8 and C9 to form C5b-8 $9_{1}$ (33). Cells incubated at $0^{\circ} \mathrm{C}$ for $60 \mathrm{~min}$ showed $15-20 \%$ lysis at a C9:C8 molar ratio of $\sim 1: 1$ (Fig. 10, $B$ and $D$ ). After washing, further incubation at $37^{\circ} \mathrm{C}$ for 60 min yielded a total lysis of $50 \%$ with no change in the $\mathrm{C} 9: \mathrm{C} 8$ ratio (Fig. $10, B$ and $E$ ). There was no significant difference in lysis or $\mathrm{C} 9: \mathrm{C} 8$ ratio when cells were incubated for $60 \mathrm{~min}$ at $37^{\circ} \mathrm{C}$ only (Fig. 10, C and F). These results cumulatively provide evidence for a minimal contribution of circular poly C9 to the lytic efficiency of MAC at low C9:C8 molar ratios. Table II summarizes the relation of specific $\mathrm{C} 8$ and $\mathrm{C} 9$ binding to formation of poly $\mathrm{C} 9$ at various C9:C8 molar ratios.

Electron microscopic studies of M21 melanoma cells killed by either $C 5 b-8$ or $C 5 b-9$. Cells bearing various numbers of $C 5 \mathrm{~b}-$ 8 or C5b-9 complexes were examined by transmission electron microscopy. Membranes of cells incubated with C8,9D serum and physiologic concentrations of $\mathrm{C} 8$ and $\mathrm{C} 9$ revealed a high density of the classical circular MAC lesions (Fig. $11 \mathrm{~A}$ ). Patching of lesions seen in most fields was attributed to antibody crosslinking of the mobile GD2 antigen as visualized by fluorescence

Table II. C9:C8 Molar Ratios and Poly C9 Formation as a Function of C8 and C9 Uptake

\begin{tabular}{|c|c|c|c|c|}
\hline $\begin{array}{l}\text { C8 molecules } \\
\text { per cell }\end{array}$ & $\begin{array}{l}\text { C9 molecules } \\
\text { per cell }\end{array}$ & C9:C8 ratio & $\begin{array}{l}\text { Poly C9 } \\
\text { per cell" }\end{array}$ & Poly C9 \\
\hline & & & & $\%$ \\
\hline $3.1 \times 10^{6}(60)^{\ddagger}$ & $1.6 \times 10^{7}(60)$ & 4.9 & $6.8 \times 10^{5}$ & 51 \\
\hline $3.1 \times 10^{6}$ & $1.1 \times 10^{7}(30)$ & 3.5 & $2.5 \times 10^{5}$ & 28 \\
\hline $3.1 \times 10^{6}$ & $6.3 \times 10^{6}(15)$ & 2.1 & $5.0 \times 10^{4}$ & 9 \\
\hline $3.1 \times 10^{6}$ & $3.3 \times 10^{6}(6)$ & 1.1 & $2.2 \times 10^{4}$ & 8 \\
\hline $9.0 \times 10^{5}(6)$ & $5.7 \times 10^{6}(60)$ & 5.9 & $1.8 \times 10^{5}$ & 37 \\
\hline $9.0 \times 10^{5}$ & $4.2 \times 10^{6}(30)$ & 4.6 & $7.3 \times 10^{4}$ & 21 \\
\hline $9.0 \times 10^{5}$ & $2.5 \times 10^{6}(15)$ & 2.5 & $1.4 \times 10^{4}$ & 7 \\
\hline $9.0 \times 10^{5}$ & $1.2 \times 10^{6}(6)$ & 1.3 & $5.0 \times 10^{3}$ & 5 \\
\hline $4.7 \times 10^{5}(3)$ & $2.7 \times 10^{6}(60)$ & 5.7 & $6.4 \times 10^{4}$ & 29 \\
\hline $4.7 \times 10^{5}$ & $1.8 \times 10^{6}(30)$ & 3.9 & $2.5 \times 10^{4}$ & 17 \\
\hline $4.7 \times 10^{5}$ & $1.2 \times 10^{6}(15)$ & 2.8 & $9.7 \times 10^{3}$ & 9 \\
\hline $4.7 \times 10^{5}$ & $6.6 \times 10^{5}(6)$ & 1.4 & $2.7 \times 10^{3}$ & 5 \\
\hline $4.7 \times 10^{5}$ & $3.7 \times 10^{5}(3)$ & 0.78 & $8.0 \times 10^{2}$ & 2.6 \\
\hline $4.7 \times 10^{5}$ & $2.1 \times 10^{5}(1.5)$ & 0.44 & $2.9 \times 10^{2}$ & 1.7 \\
\hline $5.5 \times 10^{4}(0.3)$ & $3.6 \times 10^{5}(60)$ & 6.6 & ND & ND \\
\hline $3.4 \times 10^{4}(0.15)$ & $2.2 \times 10^{5}(60)$ & 6.5 & ND & ND \\
\hline
\end{tabular}

* Calculated assuming 12 C9 monomers per SDS-resistant poly C9. ${ }^{\ddagger} \mathrm{C} 8, \mathrm{C} 9$ binding and poly $\mathrm{C} 9$ formation was determined after $60 \mathrm{~min}$ of incubation with C8,9D serum with numbers in parentheses indicating $\mathrm{C} 8, \mathrm{C} 9$ input in $\mu \mathrm{g} / \mathrm{ml}$. 


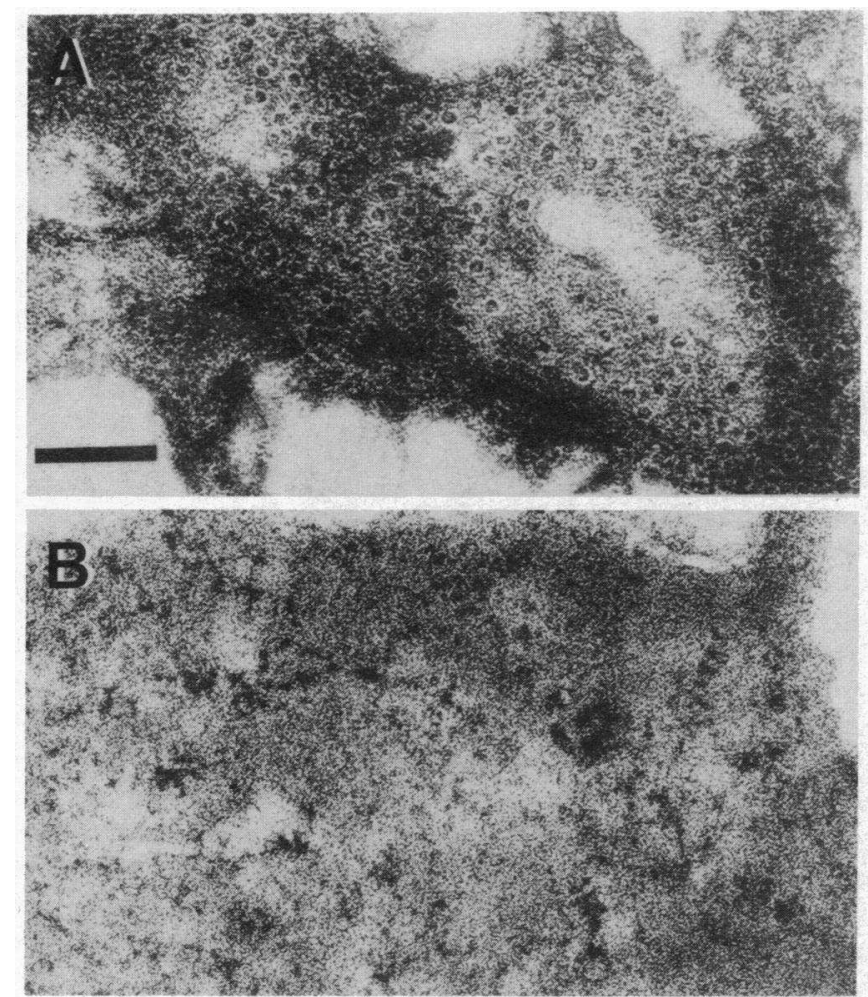

Figure 11. Transmission electron microscopy of M21 melanoma cell membranes. Cells attacked by $(A)$ C5b-9 resulting in the binding of $\sim 3 \times 10^{6} \mathrm{C} 8$ molecules per cell and $16 \times 10^{6} \mathrm{C} 9$ molecules per cell and $(B)$ C5b-8 resulting in the binding of $3 \times 10^{6} \mathrm{C} 8$ molecules/cell. Bar, $100 \mathrm{~nm}$.

microscopy. Circular lesions were not detectable at C9:C8 ratios of less than $3: 1$, regardless of C5b-8 density. Cells bearing up to $3 \times 10^{6} \mathrm{C} 5 \mathrm{~b}-8$ complexes showed no circular membrane lesions in absence of $\mathrm{C} 9$ (Fig. $11 \mathrm{~B}$ ).

Scanning electron microscopy revealed qualitative differences between cells lysed by C5b-8 and those lysed by C5b-9. M21 melanoma cells attacked by $\mathrm{C} 8,9 \mathrm{D}$ serum and physiologic doses of C8 $(60 \mu \mathrm{g} / \mathrm{ml})$ in absence of C9 showed membrane blebbing at $30 \mathrm{~min}$ (Fig. $12 \mathrm{~B}$ ), at which time all cells had released ${ }^{86} \mathrm{Rb}$ and taken up PI and 50\% had died. At 90 min $90 \%$ of the cells had died and the cell depicted in Fig. $12 \mathrm{C}$ shows vesiculation and appears collapsed. In Fig. $12 \mathrm{D}$ an M21 cell attacked by C5b-9 exhibits disintegration of its membrane structure at 30 min. The appearance of a cell treated with $\mathrm{C} 8,9 \mathrm{D}$ serum without further additions (Fig. 12 A) is similar to that of untreated cells.

\section{Discussion}

This work was conducted to determine the molecular conditions that lead to complement-mediated killing of nucleated cells with respect to $\mathrm{C} 8, \mathrm{C} 9$, and poly $\mathrm{C} 9$. The information obtained may aid in the design of immunotherapy utilizing host complement (34). It also may serve in comparing the cytotoxic efficiency of the C9-related protein of killing lymphocytes $(35,36)$ with that of $\mathrm{C} 8$ and $\mathrm{C} 9$.

The main questions addressed were $(a)$ whether tubular poly C9 was needed for the killing of nucleated human cells; $(b)$ how these cells respond to massive C5b-8 attack; and (c) which conditions of complement attack allow membrane repair and cell recovery.
Initial experiments were directed toward determining the molar C9:C8 ratio at saturation of $\mathrm{C} 9$ binding varying cell-bound $\mathrm{C} 8$ between 34,000 and 3.1 million molecules per cell. The maximal ratio achieved over this broad range was 6:1 (Fig. 3, Table II). This is an average value representing MAC structures presumably containing $0-12$ or more molecules of $\mathrm{C}$. In fact, at the highest numbers of cell-bound $\mathrm{C} 8$ and $\mathrm{C} 9$ molecules employed $\left(3.1 \times 10^{6}\right.$ and $1.6 \times 10^{7}$, respectively), the yield of poly C9 was $51 \%$ (Table II).

The experiments with C5b-8 in absence of C9 showed that membrane damage caused by $\mathrm{C} 5 \mathrm{~b}-\mathrm{8}$ is, in part, reversible and that C5b-8, at high multiplicity, is capable of killing human melanoma cells. The methodology of this study allowed correlation between the number of molecules specifically bound to the target cell and functional channel formation. Membrane leakiness due to $\mathrm{C} 5 \mathrm{~b}-8$ channels was detected by ${ }^{86} \mathrm{Rb}$ release (Fig. 4) or propidium iodide uptake (Fig. 6). ${ }^{86} \mathrm{Rb}$ release was dose dependent and rapid. It was complete at $30 \mathrm{~min}$ at which time PI uptake was maximal. Membrane permeability for PI markedly decreased thereafter and reached a constant level at 90 min of incubation, indicating membrane repair or channel elimination. Recovery by $90 \mathrm{~min}$ was between $55 \%$ and $64 \%$ under conditions at which $45-55 \%$ of cells were PI permeable at $30 \mathrm{~min}$ (Table I).

An excellent correlation was found between PI uptake and cell death as measured by ${ }^{51} \mathrm{Cr}$ release after $90 \mathrm{~min}$ of $\mathrm{C} 5 \mathrm{~b}-8$ attack (Figs. 6 and 7). This agrees with previous comparisons of these cell "viability" techniques (37). No such correlation existed at $30 \mathrm{~min}$ of incubation. At a C8 input of 3-30 $\mu \mathrm{g} / \mathrm{ml}$, PI uptake was $15-90 \%$, but there was little or no cell killing. Maximal killing (85-90\%) by C5b-8 required more than 3 million specifically bound $\mathrm{C} 8$ molecules per cell. $\mathrm{C} 5 \mathrm{~b}-8$ has been shown to bind phospholipid (38) and weaken membrane structure (39). Its membranolytic activity has been described in erythrocytes $(24,25)$, Neisseria gonorrhoeae (40) and more recently in Giardia lamblia (27) and the human cell line U937 (26). However, Escherichia coli and various cell lines have been reported to be resistant to C5b-8 $(4,10,41)$. Resistance of nucleated cells to lysis by $\mathrm{C} 5 \mathrm{~b}-8$ may be a relative phenomenon and directly related to the number of attacking C5b-8 complexes and possibly to the rate of attack. The binding curve for radiolabeled C8 (Fig. 1), representing the net effect of uptake and elimination, indicates that a rapid, overwhelming attack by $\mathrm{C} 5 \mathrm{~b}-8$ complexes is required for ultimate lysis. The M21 melanoma cell line is highly resistant to C5b-8 lysis; as many as 470,000 complexes bound per cell did not produce any detectable cell killing (Fig. 8). In contrast, in a recent study by Morgan et al. (26), U937 cells were effectively lysed by 80,000 C5b-8 complexes per cell. Homologous restriction factor (HRF), a membrane protein that interacts with C8 and $\mathrm{C} 9$ during MAC assembly and inhibits channel formation (42), was hypothesized to be at least partially responsible for the large number of $\mathrm{C} 5 \mathrm{~b}-8$ complexes required for $\mathrm{M} 21$ cell killing. However, immunoblot and FACS analyses failed to detect HRF on M21 cells. Furthermore, antiserum to HRF was unable to enhance reactive lysis of these cells (manuscript in preparation).

Two distinct C5b-9 cytolytic mechanisms may be distinguished. Using a noncytolytic amount of C5b-8 and limiting quantities of $\mathrm{C}$, the molar ratio of cell-bound C9:C8 was below 3:1 and tubular poly C9 formation was $<10 \%$ of total $C 9$ bound (Table II). Under these conditions no circular MAC images could be visualized by electron microscopic inspection of the target 

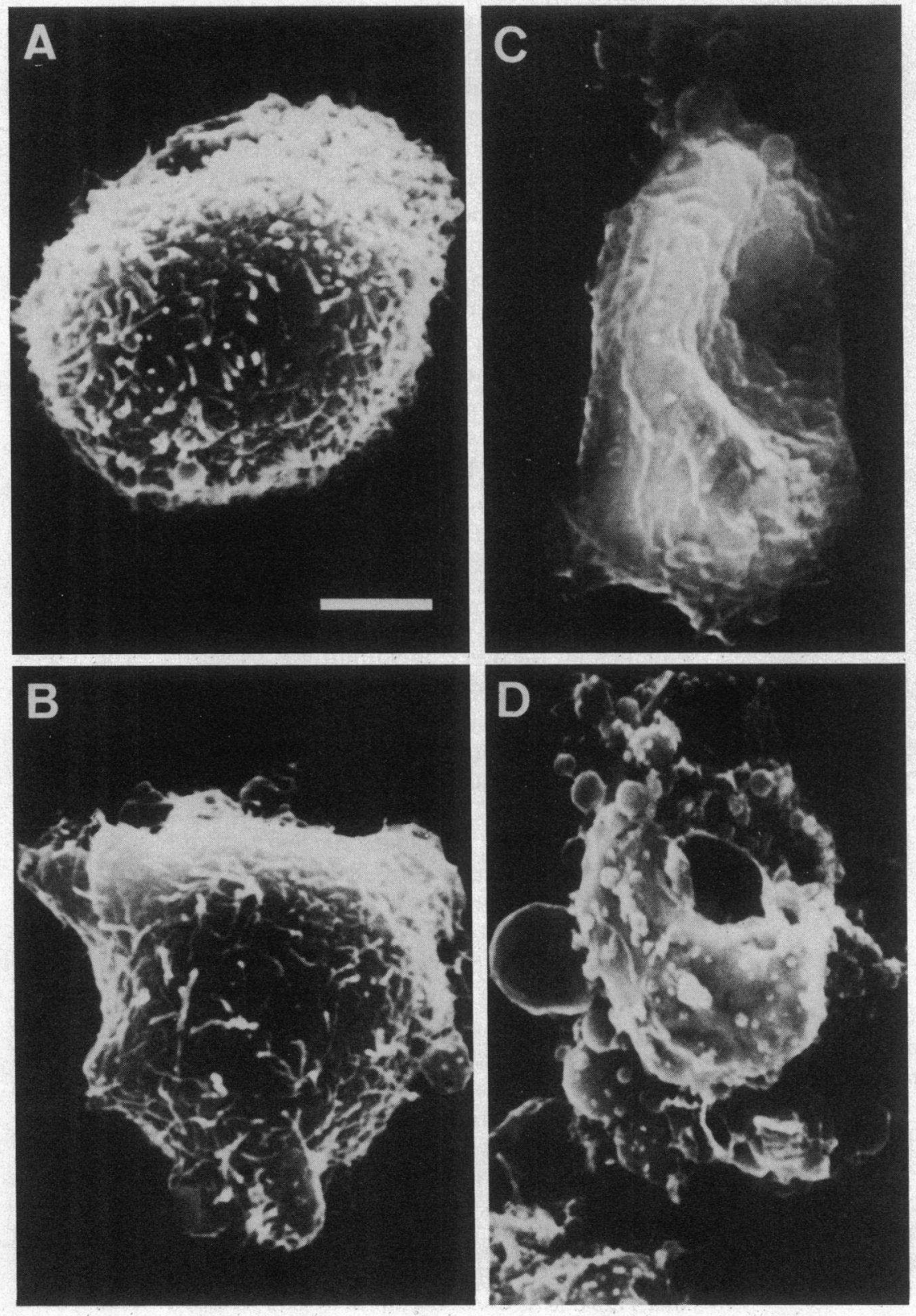

Figure 12. Scanning electron microscopy of M21 melanoma cells attacked by C5b-8 and C5b-9. Cells were incubated with $(A)$ C8,9D serum for $90 \mathrm{~min},(B, C) \mathrm{C} 8,9 \mathrm{D}$ serum reconstituted with $60 \mu \mathrm{g} / \mathrm{ml}$ of $\mathrm{C} 8$ for 30 and $90 \mathrm{~min}$, respectively, (D) $\mathrm{C} 8,9 \mathrm{D}$ serum plus $\mathrm{C} 8$ and $\mathrm{C} 9(60 \mu \mathrm{g} / \mathrm{ml})$ for $30 \mathrm{~min}$. Bar, $4 \mu \mathrm{m}$.

membranes (like Fig. $11 \mathrm{~B}$ ). However, cell killing approached $100 \%$ (Fig. 9). This mechanism is consistent with the formation of large C5b-9 aggregates in the target membrane that produce channels of various sizes and exhibit membranolytic activity. When the MAC was formed at $0^{\circ} \mathrm{C}$, consisting primarily of $\mathrm{C} 5 \mathrm{~b}$ $8_{1} 9_{1}(33)$, and the cells were washed before they were incubated at $37^{\circ} \mathrm{C}$, cell killing was similar to that observed when circular poly C9 formation was allowed to occur (Fig. 10). Thus, at low C9:C8 molar ratios, where circular poly $\mathrm{C} 9$ formation is minimized or prevented, lytic efficiency of the MAC is not impaired.

The second mechanism involves the supply of an excess of C9 which results in molar ratios of cell-bound C9:C8 approaching 6:1. Under these conditions 30 to $50 \%$ of the bound $C 9$ had formed SDS-resistant poly C9 (Table II) and clusters of negatively staining circular lesions were readily observed by electron microscopy on the membranes of the killed cells (Fig. $11 \mathrm{~A}$ ). Both mechanisms exhibit cytotoxic efficiency in the killing of human melanoma cells.

\section{Acknowledgments}

This work was supported in part by U. S. Public Health Service grants AI-17354, CA-27489, and HL-16411 and by the Price Charitable Remainder Trust. Dr. Martin is the recipient of a National Institutes of Health Physician-Scientist Award (AM-01408) administered through the University of California, San Diego. Dr. Chiu was supported by U. S. Public Health Service training grant HL-07195. Dr. Müller-Eberhard is the Cecil H. and Ida M. Green Investigator in Medical Research, Research Institute of Scripps Clinic.

\section{References}

1. Schlager, S. I., and S. H. Ohanian. 1980. Tumor cell lipid composition and sensitivity to tumoral immune killing. II. Influence of plasma membrane and intracellular lipid fatty acid content. J. Immunol. 125: 508-517.

2. Ohanian, S. H., S. I. Schlager, and S. Saha. 1982. Effect of lipids, structural precursors of lipids and fatty acids on complement-medited killing of antibody sensitized nucleated cells. Mol. Immunol. 19:535542. 
3. Schreiber, R. D., M. K. Pangburn, R. G. Medicus, and H. J. MullerEberhard. 1980. Raji cell injury and subsequent lysis by the purified cytolytic alternative pathway of human complement. Clin. Immunol. Immunopathol. 15:384-396.

4. Boyle, M. D., S. H. Ohanian, and T. Borsos. 1976. Lysis of tumor cells by antibody and complement. VII. Complement-dependent ${ }^{86} \mathrm{Rb}$ release-a nonlethal event? J. Immunol. 117:1346-1352.

5. Koski, C. L., L. E. Ramm, C. H. Hammer, M. M. Mayer, and M. L. Shin. 1983. Cytolysis of nucleated cells by complement: cell death displays multihit characteristics. Proc. Natl. Acad. Sci. USA. 80:38163820.

6. Schlager, S. I., S. H. Ohanian, and T. Borsos. 1978. Correlation between the ability of tumor cells to resist humoral immune attack and their ability to synthesize lipid. J. Immunol. 120:463-471.

7. Schlager, S. I., S. H. Ohanian, and T. Borsos. 1978. Stimulation of the synthesis and release of lipids in tumor cells under attack by antibody and C. J. Immunol. 120:895-901.

8. Imagawa, D. K., N. E. Osifchin, W. A. Paznelias, M. L. Shin, and M. M. Mayer. 1983. Consequences of cell membrane attack by complement: release of arachidonate and formation of inflammatory derivatives. Proc. Natl. Acad. Sci. USA. 80:6647-6651.

9. Campbell, A. K., and B. P. Morgan. 1985. Monoclonal antibodies demonstrate protection of polymorphonuclear leukocytes against complement attack. Nature (Lond.). 317:164-166.

10. Carney, D. F., C. L. Koski, and M. L. Shin. 1985. Elimination of terminal complement intermediates from the plasma membrane of nucleated cells: the rate of disappearance differs for cells carrying C5b7 or C5b-8 or a mixture of C5b-8 with a limited number of C5b-9. J. Immunol. 134:1804-1809.

11. Kinsky, S. C. 1972. Antibody-complement interaction with lipid model membranes. Biochim. Biophys. Acta. 265:1-13.

12. Hesketh, T. R., R. R. Dourmashkin, S. N. Payne, J. H. Humphrey, and P. J. Lachmann. 1971. Lesions due to complement in lipid membranes. Nature (Lond.). 233:620-622.

13. Lachmann, P. J., E. A. Munn, and G. Weissman. 1970. Complement-mediated lysis of liposomes produced by the relative lysis procedure. Immunology. 19:983-986.

14. Mayer, M. M. 1972. Mechanism of cytolysis by complement. Proc. Natl. Acad. Sci. USA. 69:2954-2958.

15. Podack, E. R., and J. Tschopp. 1982. Polymerization of the ninth component of complement (C9): formation of poly (C9) with a tubular ultrastructure resembling the membrane attack complex of complement. Proc. Natl. Acad. Sci. USA. 79:574-578.

16. Tschopp, J., H. J. Muller-Eberhard, and E. R. Podack. 1982. Formation of transmembrane tubules by spontaneous polymerization of the hydrophilic complement protein C9. Nature (Lond.). 298:534538.

17. Podack, E. R., J. Tschopp, and H. J. Muller-Eberhard. 1982. Molecular organization of $\mathrm{C} 9$ within the membrane attack complex of complement. J. Exp. Med. 156:268-282.

18. Sims, P. J. 1983. Complement pores in erythrocyte membranes: analysis of $\mathrm{C} 8 / \mathrm{C} 9$ binding required for functional membrane damage. Biochim. Biophys. Acta. 732:541-552.

19. Stewart, J. L., J. B. Monahan, A. Brickner, and J. M. Sodetz. 1984. Measurement of the ratio of the eighth and ninth components of human complement on complement-lysed membranes. Biochemistry. 23:4016-4022.

20. Kolb, W. P., and H. J. Muller-Eberhard. 1974. Mode of action of human C9: adsorption of multiple C9 molecules to cell-bound C8. J. Immunol. 113:479-488.

21. Ware, C. F., R. A. Wetsel, and W. P. Kolb. 1981. Physicochemical characterization of fluid phase (SC5b-9) and membrane derived (MC5B9) attack complexes of human complement purified by immunoadsorbent affinity chromatography or selective detergent extraction. Mol. Immunol. 18:521-531

22. Tschopp, J., E. R. Podack, and H. J. Muller-Eberhard. 1985. The membrane attack complex of complement: C5b-8 complex as accelerator of C9 polymerization. J. Immunol. 134:495-499.
23. Dankert, J. R., and A. F. Esser. 1985. Proteolytic modification of human complement protein C9: loss of poly (C9) and circular lesion formation without impairment of function. Proc. Natl. Acad. Sci. USA. 82:2128-2132.

24. Biesecker, G., and H. J. Muller-Eberhard. 1980. The ninth component of human complement: purification and physicochemical characterization. J. Immunol. 124:1291-1296.

25. Stolf, R. L. 1968. Immune lytic transformation: a state of irreversible damage generated as a result of the reaction of the eighth component in the guinea pig complement system. J. Immunol. 100:46-54.

26. Morgan, B. P., D. K. Imagawa, J. R. Dankert, and L. E. Ramm. 1986. Complement lysis of U937, a nucleated mammalian cell line in the absence of C9: effect of $\mathrm{C} 9$ on $\mathrm{C} 5 \mathrm{~b}-8$ mediated cell lysis. J. Immunol. 136:3402-3406.

27. Deguchi, M., F. Gillin, and I. Gigli. 1985. Killing of Giardia lamblia trophozytes by complement. Complement. 2:21. (Abstr.)

28. Tenner, A. J., P. H. Lesavre, and N. R. Cooper. 1981. Purification and radiolabeling of human Clq. J. Immunol. 127:648-653.

29. Kolb, W. P., and H. J. Muller-Eberhard. 1976. The membrane attack mechanism of complement: the three polypeptide chain structure of the eighth component. J. Exp. Med. 143:1131-1139.

30. Laemmli, U.K. 1970. Cleavage of structural proteins during the assembly of the head of bacteriophage T4. Nature (Lond.). 227:680-683.

31. Cheresh, D. A., C. J. Honsik, L. K. Staffileno, G. Jung, and R. A. Reisfeld. 1985. Disialoganglioside GD3 on human melanoma serves as a relevant target antigen for monoclonal antibody-mediated tumor cytolysis. Proc. Natl. Acad. Sci. USA. 82:5155-5159.

32. Bumol, T. F., and R. A. Reisfeld. 1982. Unique glycoproteinproteoglycan complex defined by monoclonal antibody on human melanoma cells. Proc. Natl. Acad. Sci. USA. 79:1245-1249.

33. Bhakdi, S., and J. Tranum-Jensen. 1986. C5b-9 assembly: average binding of one $\mathrm{C} 9$ molecule to $\mathrm{C} 5 \mathrm{~b}-8$ without poly-C9 formation generates a stable transmembrane pore. J. Immunol. 136:2999-3005.

34. Vogel, C-W., and H. J. Muller-Eberhard. 1981. Induction of immune cytolysis: tumor-cell killing by complement is initiated by covalent complex of monoclonal antibody and stable C3/C5 convertase. Proc. Natl. Acad. Sci. USA. 78:7707-7711.

35. Zalman, L. S., M. A. Brothers, and H. J. Muller-Eberhard. 1985. A C9 related channel forming protein in the cytoplasmic granules of human large granular lymphocytes. Biosci. Rep. 5:1093-1100.

36. Zalman, L. S., M. A. Brothers, F. J. Chiu, and H. J. MullerEberhard. 1986. Mechanism of cytotoxicity of human large granual lymphocytes: relationship of the cytotoxic lymphocyte protein to $\mathrm{C} 9 \mathrm{of}$ human complement. Proc. Natl. Acad. Sci. USA. 83:5262-5266.

37. Jacobs, D. B., and C. Pipho. 1983. Use of propidium iodide staining and flow cytometry to measure antibody-mediated cytotoxicity: resolution of complement-sensitive and resistant target cells. J. Immunol. Methods. 62:101-108.

38. Podack, E. R., G. Biesecker, and H. J. Muller-Eberhard. 1979. Membrane attack complex of complement: generation of high affinity phospholipid binding sites by the fusion of five hydrophilic, plasma proteins. Proc. Natl. Acad. Sci. USA. 76:897-901.

39. Esser, A. F., W. P. Kolb, E. R. Podack, and H. J. Muller-Eberhard. 1979. Molecular reorganization of lipid bilayers by complement: a possible mechanism for membranolysis. Proc. Natl. Acad. Sci. USA. 76: 1410-1414.

40. Schreiber, R. D., D. C. Morrison, E. R. Podack, and H. J. MullerEberhard. 1979. Bactericidal activity of the alternative complement pathway generated from eleven isolated plasma proteins. J. Exp. Med. 149:870-882.

41. Joiner, K. A., M. A. Schmitz, T. G. Murray, C. H. Hammer, R. Dourmashkin, and M. M. Frank. 1985. Multimeric complement component $\mathrm{C} 9$ is necessary for killing of Escherichia coli $\mathrm{J} 5$ by terminal attack complex C5b-9. Proc. Natl. Acad. Sci. USA. 82:4808-4812.

42. Zalman, L. S., L. M. Wood, and H. J. Muller-Eberhard. 1986. Isolation of a human erythrocyte membrane capable of inhibiting expression of homologous complement transmembrane channels. Proc. Natl. Acad. Sci. USA. 83:6975-6979. 